\title{
The Future of Transport Surveys: Users' Requirements for Official Transport Statistics
}

\author{
Elmar Wilhelm M. Fürst \\ Vienna University of Economics and Business \\ Statistics Austria, Vienna
}

\begin{abstract}
Official transport statistics is a broad, complex and important domain in the area of official statistics. Due to the dynamics of transport markets, their economic framework and legal regulation as well as the evolving challenges for transport economics, companies, research and policy the statistical users' needs are also subject to continuous change. This article presents the main results of a study conducted by the Institute of Transport and Logistics Management at Vienna University of Economics and Business which focused on the requirements on future developments in the field of official transport statistics from the users' perspective.
\end{abstract}

Keywords: Official Transport Statistics, User needs, Empirical Survey.

\section{Introduction and Background}

Transport is a mass phenomenon with direct and indirect effects for everyone and thus of general interest and particular importance. The field of transport statistics is rather complex as there are many different criteria by which transport activities can be structured, e.g. distance (short- and long-distance transport), the modes of transport (road, rail, inland waterways, sea, air, pipelines), the transport objects (passenger, freight transport), the relation to a country's national territory (inland transport, international receipt and dispatch, transit transports, cabotage, other transports abroad) to name but a few examples. Furthermore transport infrastructure, rolling stock and transport companies have also to be taken into account. The field becomes even more complex as these criteria can be combined with one another and be further itemised and subdivided.

Transport statistics are collected and compiled by companies, organisations and authorities. They are related to different points and periods of time, have different regional scopes, are partly tailor-made surveys, partly standardised, compiled once or regularly, vary significantly as regards accessibility, actuality, comparability, coherence, methods, survey designs, validity, reliability etc. Within this broad field official federal transport statistics in Austria provided by Statistics Austria is a major component. Official statistics offers many advantages for the users like harmonised legal bases in European Community law, reporting obligations, large samples or even full census surveys, impartial and transparent conditions and the application of modern scientific methods. If available, administrative data sources can be used and everyone can access both metadata and results. Furthermore the United Nations fundamental principles of official statistics (see United Nations, 2009), the European Statistics Code of Practice (see European Commission, 2009) and the Austrian Federal Statistics Act 2000 (Bundesstatistikgesetz 2000; BGB1. I Nr.163/1999, idF BGB1. 92/2007; see Statistics Austria, 2009a) apply and guarantee 
upmost standards. These facts ensure that users can legitimately rely on the results of official statistics and take them as a point of reference.

Table 1 shows an overview of the surveys regularly conducted in official transport statistics in Austria. Further details and an enumeration of legal bases can be found in the Standard documentations provided by Statistics Austria for each domain individually.

\section{Problem Statement}

The group of transport statistics' users is as heterogeneous as the statistical field itself. Representatives of transport policy on European, national and regional levels, universities, research institutes, authorities, media, various kinds of companies and other organisations need the data for their purposes e.g. transport models, forecasts, cost-benefit-analyses, project planning and investment decisions, measures to improve safety etc.

Because of the different objectives transport statistics have to fulfill, it is hardly possible to define a general profile of requirements from the users' point of view. Technical progress and particularly the availability of IT-based models and methods lead to a steady change of demand and requirements. There is also a three-tiered trade-off between high statistical quality, a reduction of respondents' burden and the economical use of resources needed for the compilation of results. This leads to a need for the development of innovative methods, automated data collection techniques and the use of administrative data.

Due to the fact that profound changes and the implementation of new techniques and systems in official transport statistics have to be based on modern legal acts, conceptual preparations and the introduction of methodological as well as technological developments take significant time. It would thus seem useful to obtain a big picture at an early stage of what users shall expect from statistical results on a regular basis from a neutral perspective. This is a prerequisite to offering high quality statistics according to users' needs in the future. It has to be found out, what data shall be collected by whom and by the use of which means. The understandable and partly rather extensive requirements on the users' side have to be deliberately regarded taking into account the need for legal bases, feasibility and financial constraints.

\section{Empirical Analysis: Method}

Users' needs and requirements for future official transport statistics have been investigated in a qualitative study by the Institute for Transport and Logistics Management of Vienna University of Economics and Business. As a first step a guideline for the structural interviews was developed. In order to identify and contact experts on several fields using transport statistics in their work, a list of relevant organisations, institutions, companies and authorities and possible contact persons was compiled. A basic distinction was made between public and private bodies which were then further assigned to subfields like authorities, consultants or companies according to modes of transport. Only the Federal Ministry for Transport, Innovation and Technology was directly included in the sample because of its importance as a high-level user, for all other respondents a random sample was drawn per subfield. Due to the high willingness to participate in the survey and thus 
Table 1: Overview on official transport statistics and its current coverage of transport.

\begin{tabular}{|c|c|c|c|c|c|c|}
\hline & $\begin{array}{l}\text { Type of sur- } \\
\text { vey }\end{array}$ & $\begin{array}{l}\text { Survey } \\
\text { principle }\end{array}$ & $\begin{array}{l}\text { Responsible } \\
\text { directorate } \\
\text { at Statistics } \\
\text { Austria }\end{array}$ & $\begin{array}{l}\text { Reporting } \\
\text { media }\end{array}$ & Units & Objects \\
\hline $\begin{array}{l}\text { Road freight } \\
\text { transport } \\
\text { of Austrian } \\
\text { companies }\end{array}$ & $\begin{array}{l}\text { Sample of } \\
\text { vehicles } \\
\text { and report- } \\
\text { ing weeks } \\
\text { (mandatory) }\end{array}$ & $\begin{array}{l}\text { Nationality } \\
\text { principle }\end{array}$ & $\begin{array}{l}\text { Business } \\
\text { Statistics }\end{array}$ & $\begin{array}{l}\text { Paper and } \\
\text { web-based } \\
\text { question- } \\
\text { naire }\end{array}$ & $\begin{array}{l}\text { Local units with } \\
\geq 1 \text { lorry with } \\
\geq 2 t \text { load capac- } \\
\text { ity or } \geq 1 \text { articu- } \\
\text { lated lorry }\end{array}$ & $\begin{array}{l}\text { Lorries with } \geq \\
2 t \text { load capac- } \\
\text { ity, articulated } \\
\text { lorries }\end{array}$ \\
\hline $\begin{array}{l}\text { Vehicle } \\
\text { stock }\end{array}$ & $\begin{array}{l}\text { Use of ad- } \\
\text { ministrative } \\
\text { data }\end{array}$ & $\begin{array}{l}\text { Territory } \\
\text { principle }\end{array}$ & $\begin{array}{l}\text { Spatial } \\
\text { Statistics }\end{array}$ & $\begin{array}{l}\text { Automated } \\
\text { data import } \\
\text { from admin- } \\
\text { istrative data } \\
\text { source }\end{array}$ & $\begin{array}{l}\text { Road motor ve- } \\
\text { hicles and trail- } \\
\text { ers approved for } \\
\text { public roads in } \\
\text { Austria and a de- } \\
\text { sign speed of } \geq \\
10 \mathrm{~km} / \mathrm{h}\end{array}$ & $\begin{array}{l}\text { Registrations of } \\
\text { new and used } \\
\text { cars }\end{array}$ \\
\hline $\begin{array}{ll}\text { Road acci- } \\
\text { dents }\end{array}$ & $\begin{array}{l}\text { Full census } \\
\text { survey }\end{array}$ & $\begin{array}{l}\text { Territory } \\
\text { principle }\end{array}$ & $\begin{array}{l}\text { Spatial } \\
\text { Statistics }\end{array}$ & $\begin{array}{l}\text { Accident } \\
\text { counting } \\
\text { form com- } \\
\text { pleted by the } \\
\text { police }\end{array}$ & $\begin{array}{l}\text { Austrian police } \\
\text { departments }\end{array}$ & $\begin{array}{l}\text { Road accidents } \\
\text { with personal } \\
\text { injuries }\end{array}$ \\
\hline $\begin{array}{l}\text { Rail trans- } \\
\text { port, infras- } \\
\text { tructure, } \\
\text { rolling } \\
\text { stock and } \\
\text { accidents }\end{array}$ & $\begin{array}{lr}\text { Full } & \text { cen- } \\
\text { sus } & \text { survey } \\
\text { (mandatory) }\end{array}$ & $\begin{array}{l}\text { Territory } \\
\text { principle }\end{array}$ & $\begin{array}{l}\text { Business } \\
\text { Statistics }\end{array}$ & $\begin{array}{l}\text { Electronic } \\
\text { data supply, } \\
\text { paper and } \\
\text { web-based } \\
\text { question- } \\
\text { naires }\end{array}$ & $\begin{array}{lr}\text { Austrian } & \text { based } \\
\text { railway under- } & \text { uk } \\
\text { takings } & \text { and } \\
\text { all companies } \\
\text { performing rail } \\
\text { transports } \\
\text { Austria }\end{array}$ & $\begin{array}{l}\text { Railway trans- } \\
\text { ports on Austrian } \\
\text { territory, rail in- } \\
\text { frastructure, } \\
\text { rolling stock, } \\
\text { accidents }\end{array}$ \\
\hline $\begin{array}{l}\text { Inland } \\
\text { waterways }\end{array}$ & $\begin{array}{lr}\text { Full cen- } \\
\text { sus survey } \\
\text { (mandatory) }\end{array}$ & $\begin{array}{l}\text { Territory } \\
\text { principle }\end{array}$ & $\begin{array}{l}\text { Business } \\
\text { Statistics }\end{array}$ & $\begin{array}{l}\text { Paper count- } \\
\text { ing forms, } \\
\text { electronic } \\
\text { data supply }\end{array}$ & $\begin{array}{l}\text { Vessels with } \geq \\
50 t \text { load capac- } \\
\text { ity }\end{array}$ & $\begin{array}{l}\text { Transports of } \\
\text { Austrian and } \\
\text { foreign ships on } \\
\text { the Danube with } \\
\text { a load capacity } \\
\geq 50 t\end{array}$ \\
\hline $\begin{array}{l}\text { Civil avia- } \\
\text { tion (passen- } \\
\text { ger, freight, } \\
\text { mail) }\end{array}$ & $\begin{array}{lr}\text { Full } & \text { cen- } \\
\text { sus } & \text { survey } \\
\text { (mandatory) }\end{array}$ & $\begin{array}{l}\text { Territory } \\
\text { principle }\end{array}$ & $\begin{array}{l}\text { Business } \\
\text { Statistics }\end{array}$ & $\begin{array}{l}\text { Electronic } \\
\text { data supply, } \\
\text { paper and } \\
\text { web-based } \\
\text { question- } \\
\text { naires }\end{array}$ & $\begin{array}{l}\text { Austrian airports } \\
\text { and airfields }\end{array}$ & $\begin{array}{l}\text { Scheduled and } \\
\text { non-scheduled } \\
\text { air transport } \\
\text { with } \geq 5.700 \\
\mathrm{~kg} \mathrm{maximum} \\
\text { permissible } \\
\text { take-off weight } \\
\text { (commercial } \\
\text { aviation) }\end{array}$ \\
\hline Pipelines & $\begin{array}{l}\text { Full census } \\
\text { survey (vol- } \\
\text { untary) }\end{array}$ & $\begin{array}{l}\text { Territory } \\
\text { principle }\end{array}$ & $\begin{array}{l}\text { Business } \\
\text { Statistics }\end{array}$ & $\begin{array}{l}\text { Electronic } \\
\text { data supply }\end{array}$ & $\begin{array}{l}\text { Companies op- } \\
\text { erating pipelines } \\
\text { for oil or gas } \\
\text { transports in } \\
\text { Austria }\end{array}$ & $\begin{array}{l}\text { Pipeline-bound } \\
\text { oil and gas } \\
\text { transports in } \\
\text { Austria }\end{array}$ \\
\hline
\end{tabular}


subfields as a replacement. In total 35 experts were contacted of which 31 eventually participated in the survey which equals a response rate of $88.6 \%$. This strengthens the presumption that official transport statistics serve as an important input factor for many kinds of tasks. Table 2 comprises the fields of work of the experts interviewed.

The experts were contacted via telephone and - whenever possible - an appointment was arranged. Most of the interviews (18) were held - as intended - face-to-face in the experts' offices. Due to time constraints (on the experts' side) eight interviews were completed via telephone. In five cases and upon explicit request a written response (via email) was also accepted. From the methodological point of view it might be criticized that faceto-face-interviews, telephone interviews and particularly written responses were treated equally. However only qualitative data was collected and official transport statistics are basically considered a less sensitive topic for interviewees than their political attitudes or even their health. Hence there is only a limited danger of obtaining social desirable answers. The small chance of a methodological bias was accepted in order not to abandon important experts' input. Similar response patterns could be taken as supporting indication for this assumption.

The interviews were conducted between March $27^{\text {th }}, 2009$ and June $4^{\text {th }}, 2009$. The average length was 35 minutes per interview. Figure 1 shows the interview structure (translated by the author, the interviews were held in German).

Table 2: Expert interviews: Overview of the interviewees' fields of work.

\begin{tabular}{lc}
\hline Area & Count \\
\hline Public authority & 6 \\
Research institute, universities & 5 \\
Rail & 4 \\
Special interest groups & 3 \\
Transport planning & 3 \\
Road & 2 \\
Aviation & 1 \\
Inland waterways & 1 \\
Telematics & 1 \\
Transport safety & 1 \\
Official transport statistics & 1 \\
Regional transport association & 1 \\
Media & 1 \\
Others & 1 \\
\hline Total & 31 \\
\hline
\end{tabular}




\section{$\mathbf{W}=$ ECONOMICS}

Guideline for expert interviews (translated into English; original: German):

For a research project at the Institute of Transport and Logistics Management of the Vienna University of Economics and Business we are conducting interviews about official transport statistics in Austria.

All interviews will be treated confidential and in the reports only the area the interview partner is working in will be stated (e.g. authority, transport company).

If you are interested in the results we will be happy to send you the final report Now we would like to discuss some questions about official transport statistics in Austria:

1. What do you think in general about official transport statistics?

(K) How would you assess the quality of official transport statistics in gereal?

(K) Could another organisation take over official transport statistics (from Statistics Austria)?

2.

a. Which data of official transport statistics is used in your organisation/company?

b. What is it used for?

c. Where do you get it from?

3. Surveys in the field of official transport statistics result in a certain burden for the respondents having to fulfil legal reporting obligations. Do you regard this as justified and reasonable? Would you improve anything at this point?

4. Now for the different domains of official transport statistics: Which room for improvement do you see concerning data collection, dissemination and quality in the field of

\begin{tabular}{|c|c|c|}
\hline & $\begin{array}{c}\text { Survey technique, } \\
\text { data collection }\end{array}$ & $\begin{array}{c}\text { Dissemination/ } \\
\text { quality }\end{array}$ \\
\hline \multicolumn{3}{|l|}{ Road freight transport statistics } \\
\hline \multicolumn{3}{|l|}{ Rail transport statistics } \\
\hline \multicolumn{3}{|l|}{ Civil aviation statistics } \\
\hline Statistics of inland waterways transport & & \\
\hline Pipeline transport statistics & & \\
\hline
\end{tabular}

5.

a. Which additional data should be collected and disseminated in official transport statistics?

(K) from your own perspective:

(K) from a rather general point of view:

b. How should this data be collected and disseminated?

6. What should be deleted from official transport statistics?

7. Do you consider it useful and feasible to provide data of official transport statistics along with other transport relevant data collected by offical and non official bodies on a joint web-based platform?

Figure 1: Interview guidelines. 


\section{Results of the Qualitative Survey}

\subsection{General Attitude Towards Official Transport Statistics}

The majority of the interviewed experts show an overall positive attitude towards official transport statistics. They also regard all legal conditions as completely fulfilled and state that data is collected and disseminated impartially and according to the standards of accountability of national statistical institutes. They attach great importance to official transport statistics for their work. For several reasons, however, the results of official transport statistics are practically never referred to as a sole reason for taking decisions. One fundamental point of criticism raised by more than half of the experts is the time gap between the period of reference and the date of data publication. According to EUregulations this period is five months which is regarded too long by most interviewees.

Another point is the non-availability of data on low regional levels for the general public. The current legal act limits the publication of data to the level of the Austrian federal states (the nine provinces). Data below this boundary is hence not being published.

Five experts would welcome a deeper cooperation between Statistics Austria's transport unit and the Federal Ministry for Transport, Innovation and Technology. This collaboration should lead to further improvements in the data and especially to a joint publication of the Ministry's results calculated by the help of the transport model for Austria ("Verkehrsmodell Österreich"). Accordingly it would again become possible to depict transport flows of all modes on Austria's national territory. Since Austria's admission to the EU in 1995 and the following change of the survey principle in road freight transport statistics to the "nationality principle" this has not been possible as only lorries with a load capacity of 2 tonnes or more and articulated lorries registered in Austria are included in the survey. Transportation performed by foreign vehicles is not included in the results, making it difficult to assess the modal split.

All experts (about a third) who are aware that for rail, inland waterways (Danube) and air transport a full census survey and a large sample survey for road freight transport is carried out, appreciate it. This is seen as an important factor enforcing quality in these domains. Respondents' reporting obligations are considered indispensable and absolutely necessary. Other positive aspects concern the cooperation and information exchange between Statistics Austria, its respondents and the users of its products, the general openness towards suggestions and improvements and the methodological and conceptual transparency shown by the extensive and complementary publication of metadata in form of standard-documentations for each statistical domain.

Contrarily specific quality limits do not remain unmentioned. Even interview partners generally assessing quality to be high see some aspects needing improvement: In addition to the long time between reference period and publication and the missing availability of regionally disaggregated data the most often mentioned aspect are the fields of transport not covered by official transport statistics (e.g. passenger transports on the road) and problems of comparability and coherence between different transport statistics and transport and other statistics respectively. The latter is of course a pan-European problem as the methods, variables, and concepts are mostly regulated by European law and thus are not subject to national decisions. 
A very clear attitude can be found concerning the question, which institution should be responsible for official federal transport statistics. The majority of the interviewed persons consider this a rather theoretical question, as there is no need to change the competent authority. Statistics Austria is seen as the responsible organisation with an experienced team and the technical resources needed.

\subsection{Use of Statistical Results in the Field of Transport}

In the course of the interviews the question was addressed, for which reasons and purposes the experts need official transport statistics data. The data is used in numerous fields. The following (not comprehensive) list shows some of the uses; however in most cases data from official transport statistics has to be combined with data from other sources.

- Depiction of developments and trends

- Origin-destination-matrices and analyses

- Transit flows

- Share of combined/intermodal transport

- Public subsidies

- Cost-effectiveness- and cost-benefit-analyses

- Infrastructure costs

- Transport forecasts (international, national, regional)

- Stock of vehicles

- Consultancy

- Special interest and lobbying

- Multimodal analyses and comparisons, modal-split

- Emissions caused by transports

- Transport planning

- Tourism statistics

- Transport models

- Transport policy

\subsection{Respondents' Burden}

Transport companies covered by surveys in the field of official transport statistics have to use time and other resources in order to comply with the reporting obligations. The consequent respondents' burden needs to be reasonable and should be restricted to a minimum but still has to be in relation to representativeness, data needs, and quality. 24 experts consider the current burden as justified and necessary, stating that representative statistics cannot be obtained without reliable data. It has to be mentioned that major reductions could already be realised by the use of online questionnaires and the reduction of the sample size in road freight transport statistics in the year 2006.

Significant measures for further reductions are seen in the use of administrative data and particularly in the implementation of IT-based methods, the use of already existing company data and the automated data collection. Of course aspects such as relevant costs, 
quality gains, legal bases, financial sources, data safety and security, and technical feasibility also have to be taken into consideration.

Two experts (both from companies) consider the respondents' burden to be too high, the rest cannot provide information on this point.

\subsection{Possible Improvements Regarding Quality, Survey Techniques and Dissemination}

The long time between the collection of data and the publication of the corresponding results is the most prominent point of criticism mentioned by more than half of the experts. Even if this delay is in line with the legal basis, the users would like to have data available earlier. The experts feel there is a lack of legal regulations forcing companies to provide accurate data more quickly. Of course data collection, submission and processing takes time, however this could be done more efficiently.

Nine experts also desire more detailed data to be available online on the website of Statistics Austria. It seems to some extent to be unknown among the interviewees that there is a broad offer of dissemination channels including the ISIS database, which should already have been alleviated by the new web design. There is also the need for more origin-destination-matrices and more explicit indications of time series' breaks, coverage of specific results, data sources etc. At this point it needs to be stressed that it is Statistics Austria's intention to provide all metadata relevant for the correct use and interpretation of the figures, for example in the detailed standard-reports which - of course - also need to be consulted by the users.

As regards road freight transport there should be a reporting obligation for foreign vehicles and transit transports. However there is currently no legal basis for such a survey. Data derived from the ministry's transport model yielding a complete depiction of all transport flows on Austria's territory could be published by Statistics Austria under the condition of co-financing.

What is also seen as a major problem is the lack of harmonised traffic counts in Austria. For some time Austria's federal states have been responsible for traffic counts using individual methods and techniques.

Some experts believe that Statistics Austria should do more than merely present statistical results. Further analyses, comparisons, discussions and interpretation of the data would be desirable. Changes in economic and legal conditions, political or economic decisions, events, crises, weather conditions, natural catastrophes etc. could therefore be taken into account.

Of paramount importance is the inclusion of pipeline transports in the legal framework. Currently only some of the data can be published due to the voluntary character of the survey.

Electronic devices and reporting should also take place in the collection of inland waterway data. As a consequence, transit flows on the Danube could be covered completely again. Statistics Austria keeps track on current developments in this field.

In civil aviation statistics the complete itinerary of the passengers starting at the first point of origin and ending at the last destination should be collected. Currently only onward destinations are available. In a complementary survey further variables (travel 
purpose, transports pre- and post-flight, nationalities, gender etc.) should be covered. Again this fails currently because of the absence of a legal basis.

\subsection{Redundant Variables, Needs for Additional Information}

In general there is the wish for more comprehensive official transport statistics. Around $90 \%$ of all persons interviewed claimed that up to at least a certain extent official transport statistics do not cover all fundamentally relevant fields. This refers especially to mobility surveys, road passenger transports, public transport, individual transport and to multimodal transport chains in passenger and freight transport. Also other aspects of freight transport should be covered like the activities of foreign lorries on Austria's territory, activities of lorries below the current threshold in road freight transport (smaller lorries), supply chains including intramodal and intermodal transhipments, costs and prices for transport services, costs for infrastructure use and external costs. Experts would also like to see further analyses and combinations with other statistical fields (e.g. number of employees in the transport sector).

At the moment there seems to be no danger of an information overflow. On the contrary the principle "the more data - the better" seems to apply. Hence practically no survey regularly conducted is regarded as redundant.

Clearly this wish needs to be aligned to a legal mandate, feasibility and financial viability.

\subsection{Assessment of a Unique Transport Statistics Data Platform}

The experts interviewed for this study showed a clear preference for the implementation of a unique web-based transport statistics data platform following the example of Germany. All official transport statistics along with all data collected by public entities, public companies, or companies financed significantly by public bodies should be made available there. Except for one single expert this proposition is strongly supported.

\section{Conclusions}

The general attitude among the interviewed transport experts towards official transport statistics is excellent. The users seem to be satisfied with the results and efforts of Statistics Austria. The resources currently used for official transport statistics and the respondent's burden is seen as being absolutely justified.

Improvements could be achieved for instance by reducing the time period between collection and publication of data, by making more detailed regional results available, by a more comprehensive coverage of transport flows, further by the inclusion of all methods of transport in Austria, by a significant extension of the transport statistical scope, by the establishments of links to other statistics, and even by further analyses and interpretation of developments as well as forecasts. All this could be provided, though, if legal or contractual assignments and financial resources are assured.

The interviews also show that the spectrum of available dissemination channels (see Statistics Austria, 2009b) and publications is not known even to some experts. This could 
induce a leaner dissemination concept. Similarly the ISIS database, web-questionnaires and standard-documentations containing all relevant metadata are not always known. There is a need to make these information sources more public, as ignorance may lead to misinterpretation of data and a rising number of interventions and inquiries. The new website has already brought more transparency in this context.

The study allows - all-in-all - deeper insight into the users' needs and requirements. Not surprisingly although general satisfaction with the results of official transport statistics is high, many fields could be detected where improvements are desired by the experts relying on well founded transport figures. Even if not all wishes are being fulfilled the study provides some orientation and helps to work on a list of priority measures.

At the same point it has to be made clear that the realisation of new surveys is not at the disposal of Statistics Austria but rather a political question. In every case, a legal basis and the required financial means have to be provided according to the Federal Statistics Act 2000 .

A key question in and fundamental precondition for many developments in the field of official transport statistics is the further progress of the drafted new Transport Statistics Act which - hopefully - will be finished and eventually published in the near future. This new national law would lead to a more flexible approach and many other advantages for respondents, compilers and users of official transport statistics ensuring that users' requirements can also be met in the future.

\section{Acknowledgements}

The author would like to thank Viktor Földi and Peter Oberhofer, both students at the Institute for Transport and Logistics Management of Vienna University of Economics and Business, for their valuable contributions as research assistants to the project, particularly for conducting the interviews with the 31 experts and Guy Delpech for proof-reading the manuscript.

\section{References}

European Commission. (2009). European statistics code of practice for the national and community statistical authorities. Website. (http://epp. eurostat.ec.europa .eu/portal/page/portal/quality/documents/codel_practice.pdf; accessed 16-Dec-2009)

Statistics Austria. (2009a). The federal statistics act (consolidated version, translated). Website. (http://www.statistik.at/web_en/about_us/responsibilities _and_principles/statistics_act/index.html; accessed 16-Dec-2009)

Statistics Austria. (2009b). Publications and services. Website. (http://statistik.gv .at/web_en/publications_services/index.html; accessed 16-Dec-2009)

United Nations. (2009). The united nations fundamental principles of official statistics. Website. (http://www.statistik.at/web_en/about_us/ responsibilities_and_principles/the_united_nations_fundamental _principles_of_official_statistics/index.html; accessed 14-Oct-2009) 
Author's address:

Elmar Wilhelm M. Fürst

Institute for Transport and Logistics Management

Vienna University of Economics and Business

1090 Vienna

E-mail: elmar.fuerst@wu.ac.at

and

Statistics Austria

Directorate Business Statistics

Transport Statistics

Guglgasse 13

1110 Vienna

E-mail: elmar.fuerst@statistik.gv.at 